\title{
A reporting guide for qualitative studies
}

\author{
Correspondence: ccdr-rmtc@phac-aspc.gc.ca
}

Suggested citation: A reporting guide for qualitative studies. Can Comm Dis Rep 2016;42:177-8. https://doi.org/10.14745/ccdr.v42i09a02

Qualitative studies provide insight into complex phenomena. Unlike measurement-based studies which typically quantify what happens under experimental conditions, qualitative studies often help explain behaviours or perceptions under actual circumstances. Qualitative studies in the field of communicable diseases can be used to provide insights into why people choose high-risk behaviours and to identify factors that influence their decisions. For example, a qualitative study may address why healthcare practitioners do not practice adequate hand hygiene and whether patients might help by reminding them to do so. The results can be surprising. For example, a recent study identified that inpatients in one hospital who were most dissatisfied with the care they received were also the least likely to ask healthcare professionals if they had washed their hands (1). Furthermore, the study identified that the decision not to pose this question was linked to patient awareness that staff satisfaction was low.

Qualitative research analyzes data from direct field observations, in-depth, open-ended interviews and written documents. Inductive analyses yield patterns and themes that generate hypotheses and offer a basis for future research. Although qualitative studies do not create generalizable evidence, well-reported studies provide enough information for readers to assess the applicability or transferability of findings to their own context (2).

There are a variety of checklists on how to report qualitative studies (3-6). The Canada Communicable Disease Report (CCDR) has developed a 24-item checklist that synthesizes these including the COREQ checklist noted on the EQUATOR Network (6). The CCDR checklist identifies the importance of describing how data was gathered and summarized, what trends were determined, exploring corroborative findings, offering alternative explanations and identifying possible next steps (Table 1).

Reports of qualitative studies are usually around 2,500 words in length-excluding the abstract, tables and references. As with all submissions, check CCDR's Information for authors, published at the beginning of each volume in January of each year for general manuscript preparation and submission requirements (7).
Table 1: Checklist for qualitative studies

\begin{tabular}{|c|c|c|}
\hline Reporting item & No. & Description \\
\hline \multicolumn{3}{|l|}{ Title/Abstract } \\
\hline Title & 1 & $\begin{array}{l}\text { Compose a title that includes the term } \\
\text { "qualitative", the population, condition, } \\
\text { place and time. }\end{array}$ \\
\hline Abstract & 2 & $\begin{array}{l}\text { Use a structured abstract format with the } \\
\text { following section headings: Background, } \\
\text { Objective, Methods, Findings and } \\
\text { Conclusion. }\end{array}$ \\
\hline \multicolumn{3}{|l|}{ Introduction } \\
\hline Issue identification & 3 & $\begin{array}{l}\text { Identify the topic of the study and why it } \\
\text { is important. }\end{array}$ \\
\hline Review of literature & 4 & $\begin{array}{l}\text { Provide a summary of the literature } \\
\text { relating to the topic and what gaps there } \\
\text { may be. }\end{array}$ \\
\hline Rationale for study & 5 & $\begin{array}{l}\text { Identify the rationale for the study. } \\
\text { The rationale for the use of qualitative } \\
\text { methods can be noted here or in the } \\
\text { methods section. }\end{array}$ \\
\hline Objective & 6 & $\begin{array}{l}\text { Clearly articulate the objective of the } \\
\text { study. }\end{array}$ \\
\hline Ethics approval & 7 & $\begin{array}{l}\text { Note here or in the methods section } \\
\text { whether ethics board review was } \\
\text { indicated, and if it was, where review and } \\
\text { approval was obtained. }\end{array}$ \\
\hline \multicolumn{3}{|l|}{ Method } \\
\hline Setting & 8 & $\begin{array}{l}\text { Describe the setting of the study and the } \\
\text { relationship of the researcher to study } \\
\text { participants (if any). }\end{array}$ \\
\hline Approach & 9 & $\begin{array}{l}\text { Identify the qualitative methods (e.g., } \\
\text { interviews, participant observation) } \\
\text { used in the study, any theoretical } \\
\text { underpinnings if appropriate (e.g., } \\
\text { grounded theory) and the rationale for } \\
\text { their use. }\end{array}$ \\
\hline Populations & 10 & $\begin{array}{l}\text { Describe the groups from which people } \\
\text { were invited to participate in the study. }\end{array}$ \\
\hline Sampling & 11 & $\begin{array}{l}\text { Identify the sampling strategies for } \\
\text { the study (e.g., theoretical sampling, } \\
\text { snowball technique). }\end{array}$ \\
\hline Data collection & 12 & $\begin{array}{l}\text { Describe how data collection tools were } \\
\text { developed (e.g., pilot testing of interview } \\
\text { guides) and how the data were recorded } \\
\text { (e.g., audio, audiovisual or field notes). }\end{array}$ \\
\hline
\end{tabular}




\begin{tabular}{|c|c|c|}
\hline Analysis & 13 & $\begin{array}{l}\text { Identify how the data were managed } \\
\text { and analyzed, including any software } \\
\text { system used, and how information was } \\
\text { assessed for credibility and transferability } \\
\text { (e.g., member checking, inter-observer } \\
\text { reliability and triangulation). }\end{array}$ \\
\hline Synthesis & 14 & $\begin{array}{l}\text { Describe how the findings were } \\
\text { synthesized (e.g., what were the } \\
\text { principles and choices informing the } \\
\text { recognition of patterns and formation of } \\
\text { categories? How were major and minor } \\
\text { themes developed?). }\end{array}$ \\
\hline \multicolumn{3}{|l|}{ Findings } \\
\hline Sample & 15 & $\begin{array}{l}\text { Identify the total sample size and } \\
\text { non-participation rate. }\end{array}$ \\
\hline $\begin{array}{l}\text { Population, time } \\
\text { and place }\end{array}$ & 16 & $\begin{array}{l}\text { Present the findings in context, i.e., with } \\
\text { enough background and contextual } \\
\text { detail to give a sense of the population, } \\
\text { time and place (e.g., through appropriate } \\
\text { use of quotes). }\end{array}$ \\
\hline Analysis & 17 & $\begin{array}{l}\text { Present an analysis that is credible and } \\
\text { compelling (i.e., themes flow logically } \\
\text { from the findings; relations between data } \\
\text { and theoretical models and perspectives } \\
\text { are described; interpretations are } \\
\text { insightful). }\end{array}$ \\
\hline Comparisons & 18 & $\begin{array}{l}\text { Explore corroborative findings (e.g., } \\
\text { triangulation) and consider contradictory } \\
\text { or diverse opinions (e.g., negative cases). }\end{array}$ \\
\hline Synthesis & 19 & $\begin{array}{l}\text { Present findings in such a way that they } \\
\text { clearly address the research objective. }\end{array}$ \\
\hline \multicolumn{3}{|l|}{ Discussion } \\
\hline $\begin{array}{l}\text { Summary of key } \\
\text { findings }\end{array}$ & 20 & $\begin{array}{l}\text { Summarize key findings and indicate how } \\
\text { the findings are relevant to the objective } \\
\text { of the study. }\end{array}$ \\
\hline $\begin{array}{l}\text { Strengths and } \\
\text { weaknesses }\end{array}$ & 21 & $\begin{array}{l}\text { Identify the strengths and weaknesses } \\
\text { of the study and consider alternative } \\
\text { explanations for the findings when } \\
\text { appropriate. }\end{array}$ \\
\hline Transferability & 22 & $\begin{array}{l}\text { Explore the implications of the study } \\
\text { considering the applicability or } \\
\text { transferability of the findings. }\end{array}$ \\
\hline Next steps & 23 & $\begin{array}{l}\text { Propose next steps or further areas of } \\
\text { inquiry. }\end{array}$ \\
\hline Conclusion & 24 & $\begin{array}{l}\text { Ensure the conclusion integrates the data } \\
\text { and analysis and addresses the objective } \\
\text { of the study. }\end{array}$ \\
\hline
\end{tabular}

\section{References}

1. Ahmad R, Iwami M, Castro-Sánchez E, Husson F, Taiyari $\mathrm{K}$, Zingg W, Holmes A. Defining the user role in infection control. J Hosp Infect. 2016 Apr;92(4):321-7. doi: 10.1016/j. jhin.2015.09.018.

2. Lincoln YS, Guba EA. Naturalistic inquiry. Beverly Hills, CA: Sage; 1985.

3. Tong A, Sainsbury P, Craig J. Consolidated criteria for reporting qualitative research (COREQ): a 32-item checklist for interviews and focus groups. Int J Qual Health Care 2007 Dec;19(6):349-57

4. Mays N, Pope C. Qualitative research in health care. Assessing quality in qualitative research. BMJ. 2000 Jan $1 ; 320(7226): 50-2$.

5. Rowan M, Huston P. Qualitative research articles: information for authors and peer reviewers. CMAJ 1997 Nov 15;157(10):1442-6.

6. Equator Network. Enhancing the QUAlity and Transparency Of health Research. Oxford: EQUATOR Network; 2015. http://www.equator-network.org/.

7. Information for authors. Can Comm Dis Rep 2016;42:20-1. http://www.phac-aspc.gc.ca/publicat/ccdr-rmtc/16vol42/drrm42-1/ar-04-eng.php. 